\title{
ANALÝZA NEHODOVÉHO DEJA NEHODOVEJ UDALOSTI NA ŽELEZNIČNOM PRIECESTÍ
}

\section{ANALYSIS OF THE ACCIDENTAL EVENT OF AN ACCIDENTAL EVENT AT THE RAILWAY CROSSING}

Michal Ballay ${ }^{1, *}$, Ludmila Macurová2

\begin{abstract}
Abstrakt Príspevok sa zameriava na problematiku bezpečnosti na železničných priecestiach, ktoré predstavujú $v$ železničnej doprave vel'mi dôležitý prvok. Zo štatistických údajov vyplýva, že nehody na železničných priecestiach predstavujú viac ako štvrtinu všetkých nehôd na železnici v rámci EU. Popri štatistickým ukazovatel'om nehodovosti na železničných priecestiach, autori príspevku mali k dispozícií podrobné údaje o tragickej nehode z roku 2009, kde došlo k usmrteniu dvanástich osôb, ako aj k d’alším vážnym zraneniam osôb. Podl'a analýzy príčin a priebehu nehody vyplýva, aké dôležité je, aby na železničných priecestiach, kde nie je možné mimoúrovňové míňanie cestnej a železničnej dopravy boli nasadené najmodernejšie zabezpečovacie prvky.
\end{abstract}

Klíčová slova železničné priecestia, bezpečnost', nehodová udalost', účastníci

Summary The paper focuses on the issue of safety at level crossings, which are a very important element in rail transport. Statistics show that road accidents account for more than a quarter of all rail accidents in the EU. In addition to statistical indicators of accidents at railway crossings, the authors of the article had at their disposal detailed data on the tragic accident from 2009, where twelve people were killed, as well as other serious injuries. According to the analysis of the causes and course of the accident, it shows how important it is to use the most modern security elements at railway crossings, where it is not possible to pass road and rail traffic off-level.

Keywords railway crossings, safety, accident, participants

\section{1 ÚVOD}

Železničné priecestia sú v oblasti dopravy vel'mi významné, nakol'ko predstavujú možnost' stretu dvoch rôznych infraštruktúr, ktorých systém riadenia podlieha odlišným predpisom, výkonom a konštrukčným riešeniam. V období posledných desat'ročí sa dopravná nehodovost' na železničných priecestiach stala častým negatívnym javom (stret účastníkov cestnej premávky s kol'ajovými vozidlami) so smrtel'nými následkami a rozsiahlymi materiálnymi škodami. Z uvedeného dôvodu predstavujú železničné priecestia vysoko rizikové miesta, s vysokým potenciálom vzniku nehodovej udalosti.

Problematika dopravnej nehodovosti je vážny celospoločenský problém premietajúci sa vo všetkých sférach l'udskej činnosti, preto si vyžaduje komplexný a racionálny prístup. Európske inštitúcie už viackrát deklarovali, že bezpečnost' Európskej únie je základom bezpečnosti l'udí a pre plánovanie hospodárskych

1 Žilinská univerzita v Žiline, Fakulta bezpečnostného inžinierstva, Katedra technických vied a informatiky, Adresa: Ul. 1. mája 32, 01026 Žilina, kontakt: michal.ballay@fbi.uniza.sk

2 Ústav znaleckého výskumu a vzdelávania, Adresa: Ul. 1. mája 32, 01026 Žilina, kontakt: ludmila.macurova@uzvv.uniza.sk

*korespondenční autor: Michal Ballay, e-mail: michal.ballay@fbi.uniza.sk 
investícií, prosperity a slobody. V kontexte tzv. „Štokholmského programu“ téma bezpečnosti prispieva $\mathrm{k}$ vytváraniu politiky celoeurópskeho priestoru, spravodlivosti, ochrany obyvatel'stva, energií, európskeho rozvoja a prostredia. Okrem toho, touto témou sa významne prispieva $\mathrm{k}$ inovácii a $\mathrm{k}$ posilneniu potreby medzinárodnej spolupráce a pomoci (Lex-europa).

\section{BEZPEČNOSŤ NA ŽELEZNIČNÝCH PRIECESTIACH}

Železničné priecestie možno charakterizovat' ako úrovňové križovanie železničnej dráhy s pozemnou komunikáciou v rámci ktorého má prevádzka dráhy prednost' pred cestnou premávkou. Toto križovanie musí byt' označené podl'a stanovených pravidiel pre dráhy, v súlade s pravidlami cestnej premávky. Z hl'adiska zabezpečenia možno rozdelit' železničné priecestia na aktívne (zabezpečené), ktoré sú vybavené priecestným zabezpečovacím zariadením a označené dopravnými značkami a pasívne (nezabezpečené), ktoré sú označené iba dopravnými značkami. Zabezpečenie železničného priecestia závisí od druhu železničnej trate a pozemnej komunikácie, ako aj od rozhl'adových a miestnych pomerov. (ŽSR)

Priame hodnotenie bezpečnosti na železničnom priecestí je vel'mi náročné, a preto je nevyhnutné vznik dopravnej nehody chápat’ ako výsledok komplexu najrôznejšieho druhu a pôsobenia. Pre zamýšlanie sa nad bezpečnost'ou železničných priecestí musí existovat' vhodná definícia, ktorá stručne a zretel'ne identifikuje, čo je a nie je zastúpené alebo je implicitne týmto termínom.

Terminologický slovník krízového riadenia definuje bezpečnost’ ako „stav spoločenského, prírodného, technického, technologického systému alebo iného systému, ktorý v konkrétnych vnútorných a vonkajších podmienkach umožňuje plnenie stanovených funkcií a ich rozvoj v záujme človeka a spoločnosti“. (Šimák, 2005)

Zo strany tvorcov politík, dopravných odborníkov, médií a verejnosti je bezpečnost' na železničných priecestiach zvyčajne chápaná ako súhrn počtu dopravných nehôd na železničných priecestiach, ich následkov a priebehu určitého časového obdobia. V rámci štatistických údajov Železníc SR je zaznamenaný podstatný rozdiel v počte železničných priecestí, vzniknutých nehôd, ako aj usmrtených osôb alebo t’ažko zranených osôb v období rokov 2010 - 2019. V sledovanom období bolo zrušených 138 železničných priecestí, klesol počet vzniknutých nehôd, počet usmrtených osôb, ale naopak, vzrástol počet osôb s následkami t’ažkých zranení. Vzhl'adom k uvedenému široko akceptovatel'nému poňatiu bezpečnosti je fókus presunutý tak, aby odrážal vznik a existenciu úrazov a smrtel'ných nehôd ako meradla toho, čo možno najlepšie opísat'.

Bezpečnost' na železničných priecestiach by mala byt' zastúpená ako kontinuum, ktoré sa tiahne od štandardného bezpečného správania zainteresovaných účastníkov dopravy vo vzt’ahu $\mathrm{k}$ dopravnej nehode, čo umožňuje konektivitu medzi prístupom zdola nahor k bezpečnosti dopravy. Je nevyhnutné stanovit' vzt'ahy medzi jednotlivými úrovňami, ako navrhol Von Klebelsburg na Obr. 1. (Svensson, 1992)

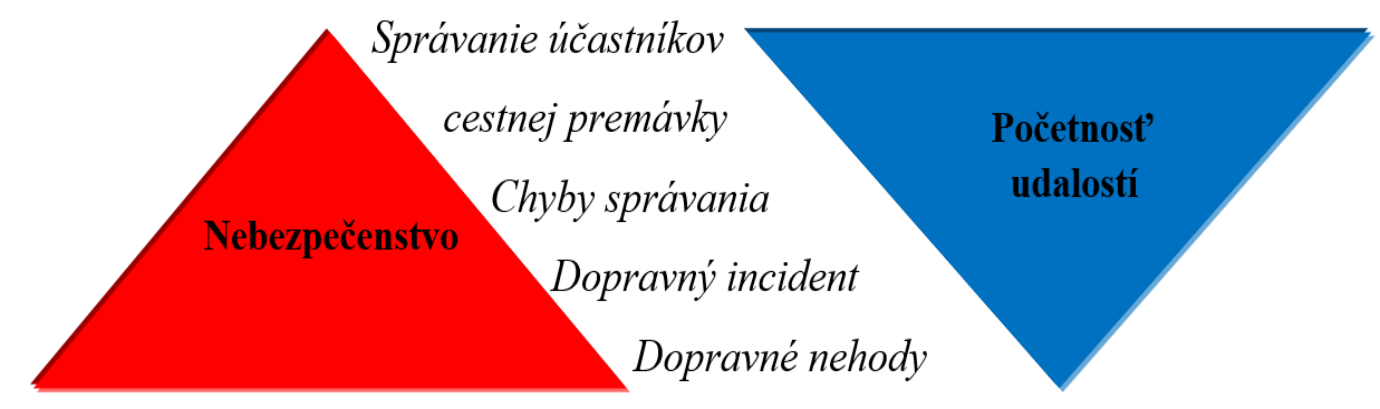

Obr. 1 Bezpečnost' cestnej premávky vo vzt’ahu k štandardnému správaniu, chybám v správaní pri riadení, dopravným konfliktom a nehodám (Podl'a: Svensson, 1992) 
Benjamin Franklin vo svojej publikácií Poor Richard's Almanack, napísal: Kvôli klincu, prišli o podkovu. Kvôli podkove o koňa. Kvôli koňovi o jazdca. Kvôli jazdcovi prehrali bitku a v bitke prišli o král'ovstvo. A to všetko pre obyčajný klinec z podkovy! Toto platí do značnej miery aj pri bezpečnosti, nakol'ko nehody môžeme označit' za mnohostranné. Prevencia v tomto smere je zameraná na odstránenie kauzálnych faktorov či zasahovanie do vzt'ahu medzi nimi.

Z matematicko - štatistického hl'adiska možno výskyt dopravných nehôd na železničnom priecestí považovat' za vyskytujúce sa nerovnomerne rozložené javy. V súčasnosti existuje v EÚ približne 120000 železničných prejazdov. Z uvedeného počtu je 60000 aktívnych železničných priecestí, ktoré sú vybavené zabezpečovacím zariadením. Tieto priecestia sa vyznačujú dobrým bezpečnostným záznamom. Druhá polovica predstavuje pasívne železničné priecestia, ktoré sú vybavené dopravným značením. Práve na týchto priecestiach dochádza najčastejšie k dopravným nehodám. Odhady trendov v počte nehôd a d'alšie výsledky v krajinách EÚ ukazujú, že zatial' čo počet vážnych nehôd na železničných priecestiach sa od roku 2006 znižuje rovnomerne, v priemere o 15 \% ročne, počet následkov dopravných nehôd je takmer konštantný. Na obrázku 2 je znázornený počet usmrtených osôb a t’ažko zranených osôb na železničných priecestiach v prepočte na milión vlakových kilometrov v období rokov 2010 - 2019.

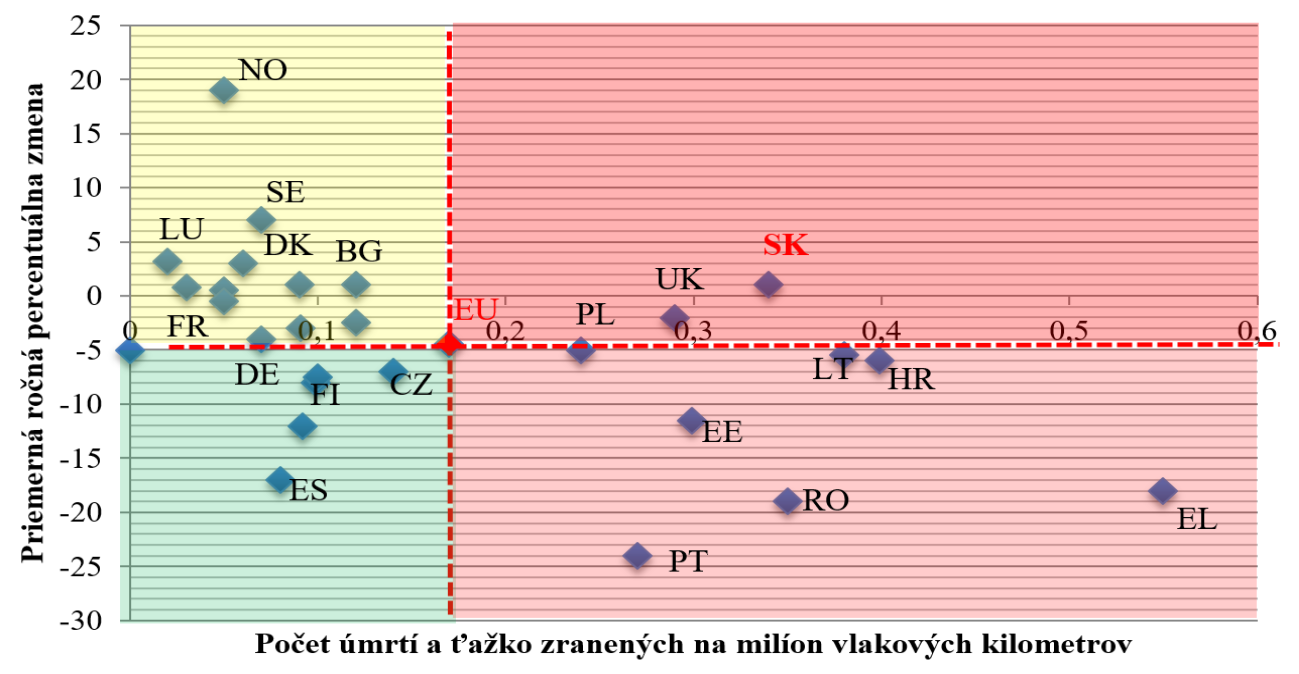

Obr. 2 Počet úmrtí a t’ažko zranených osôb na milión vlakových kilometrov vo vzt'ahu k priemernej ročnej percentuálnej zmene od roku 2010 - 2019

Priemer EÚ z týchto dvoch ukazovatel'ov rozdelil diagram na štyri kvadranty, ktoré rozdel'ujú členské krajiny do kategórií, ktoré udávajú mieru rizika následkov dopravných nehôd na železničných priecestiach. Výkonnost' bezpečnosti je podl'a najnovšieho posúdenia označovaná za prijatel'nú, v rámci EU. Zhoršenie v oblasti bezpečnosti bolo identifikované $v$ siedmich prípadoch. $V$ danej súvislosti sa používajú kategórie rizika, ktoré sú definované v smernici o bezpečnosti.

Pre kategóriu cestujúcich sa uplatňujú dve opatrenia, ktorými sú smrtel'né úrazy a vážne zranenia na jeden vlakový kilometer a smrtel'né úrazy, ako aj vážne zranenia na jeden osobokilometer. Smrtel'né a vážne zranenia znamenajú meranie následkov významných nehôd kombinujúce smrtel'né zranenia a vážne zranenia, kde vážne zranenie sa považuje za štatisticky ekvivalent s 0,1 smrtel'nými následkami. 


\begin{tabular}{|c|c|c|c|c|c|c|c|c|c|c|c|c|c|c|}
\hline & LT & HR & CZ & LV & PT & FR & IT & SE & HU & NO & BG & RO & SK & TOTAL \\
\hline 2008 & 0 & 0 & 0 & 0 & 0 & 0 & 0 & 0 & 0 & 0 & 0 & 4 & 0 & 4 \\
\hline 2009 & 1 & 0 & 0 & 0 & 0 & 0 & 0 & 0 & 0 & 0 & 0 & 4 & 4 & 9 \\
\hline 2010 & 0 & 0 & 0 & 0 & 0 & 0 & 0 & 1 & 0 & 0 & 0 & 0 & 0 & 1 \\
\hline 2011 & 0 & 0 & 0 & 0 & 0 & 0 & 0 & 1 & 0 & 0 & 1 & 4 & 4 & 10 \\
\hline 2012 & 0 & 1 & 0 & 0 & 0 & 0 & 0 & 1 & 0 & 1 & 2 & 2 & 1 & 8 \\
\hline 2013 & 0 & 0 & 0 & 0 & 0 & 0 & 1 & 0 & 0 & 2 & 1 & 1 & 2 & 7 \\
\hline 2014 & 0 & 0 & 0 & 0 & 0 & 1 & 1 & 1 & 2 & 2 & 1 & 1 & 2 & 11 \\
\hline 2015 & 0 & 0 & 0 & 0 & 0 & 0 & 1 & 1 & 0 & 3 & 1 & 0 & 2 & 8 \\
\hline 2016 & 0 & 0 & 0 & 0 & 0 & 0 & 1 & 0 & 2 & 0 & 2 & 0 & 1 & 6 \\
\hline 2017 & 0 & 0 & 0 & 0 & 0 & 1 & 0 & 0 & 0 & 1 & 0 & 0 & 1 & 3 \\
\hline 2018 & 0 & 0 & 1 & 1 & 1 & 1 & 0 & 0 & 1 & 0 & 1 & 0 & 1 & 7 \\
\hline TOTAL & 1 & 1 & 1 & 1 & 1 & 3 & 4 & 5 & 5 & 9 & 9 & 16 & 18 & \\
\hline
\end{tabular}

Obr. 3 Prípady možného/pravdepodobného zhoršenia bezpečnostnej výkonnosti v EU. (EU,2020)

Manažéri infraštruktúry železníc členských krajín EÚ pravidelne vydávajú vyhlásenia o tom, že asi 95 \% dopravných nehôd na železničných priecestiach je spôsobených účastníkmi cestnej premávky, ktorí úmyselne alebo neúmyselne porušujú pravidlá cestnej premávky. V rámci analýz rôznych nehôd stretu vlaku a cestného vozidla na železničnom priecestí bolo častokrát zistené, že vodič vbehol priamo pod prichádzajúci vlak (aj pri správnej činnosti priecestných zabezpečovacích zariadení). Brzdná dráha vlaku môže byt' až 1000 m, v závislosti od jeho hmotnosti a rýchlosti. Ďalším vel'kým problémom je vandalizmus, čím dochádza k úmyselnému poškodzovaniu priecestných zabezpečovacích zariadení (rozbitá optika výstražných svetiel, zlomené rahná, poškodené alebo vyvrátené stojany, krádeže komponentov zabezpečovacieho zariadenia, atd'.). Následkom aj malej materiálnej škody môže vzniknút' nehoda s trvalými zdravotnými následkami osôb alebo s usmrtením osôb. (ŽSR)

Nehody na železničných priecestiach v Slovenskej republike zaznamenávajú stagnujúci počet, ale ich následky sú ovel’a závažnejšie v počte usmrtených a t’ažko zranených. V železničných štatistikách (obrázok 4) nehodovosti však pripadá na železničné priecestia významný podiel.

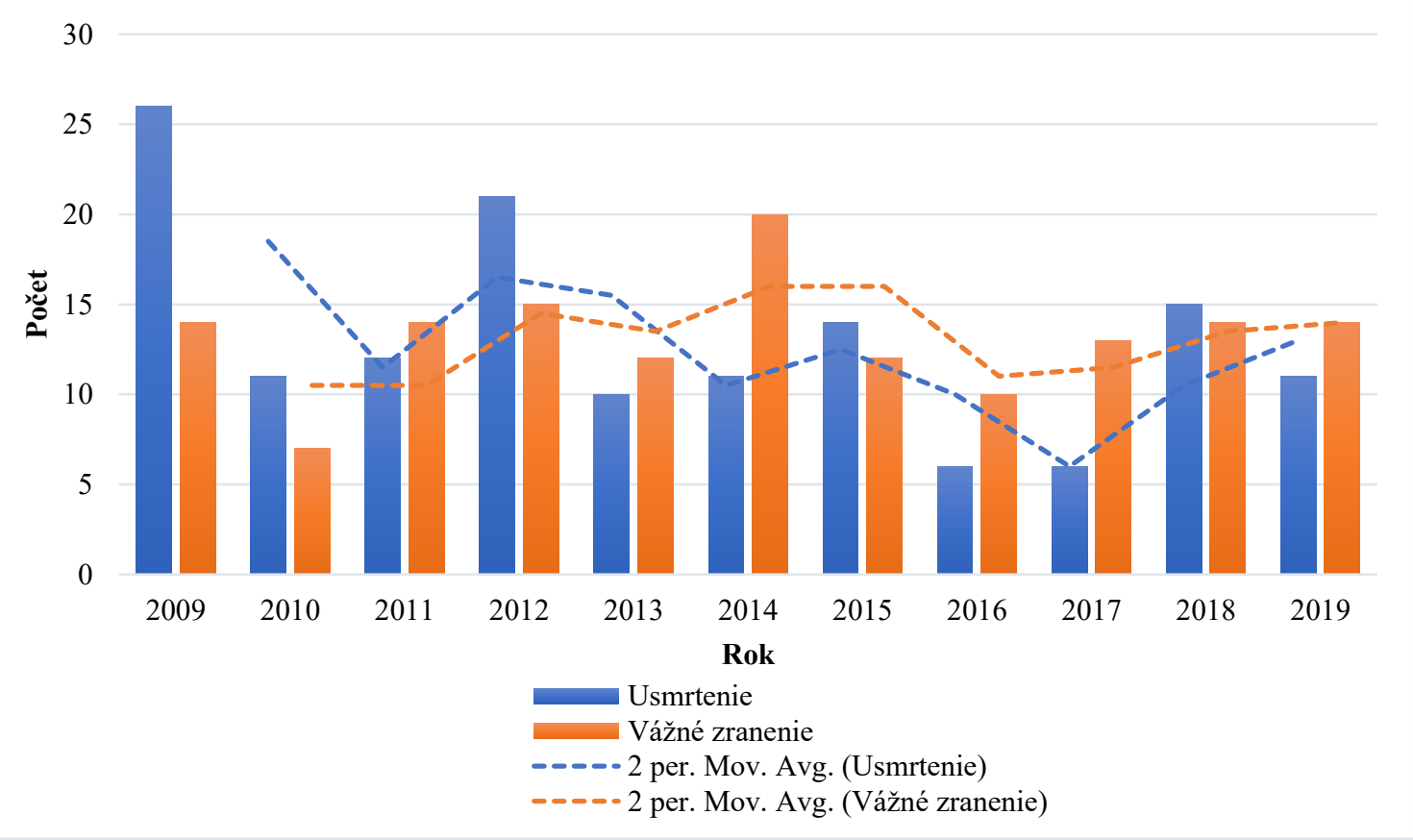

Obr. 4 Počet následkov dopravných nehôd na železničných priecestiach v SR (Podl’a: ŽSR, 2020) 
Aj vzhl'adom na stúpajúci počet nehôd a počet osôb usmrtených kol'ajovými vozidlami, ŽSR neustále apelujú na účastníkov cestnej premávky a aj na ostatné osoby, aby prehodnotili svoje správanie pri prechádzaní cez železničné priecestie a pri pohybe v blízkosti železničnej trate si počínali mimoriadne opatrne a dodržiavali ustanovenia zákona o premávke na pozemných komunikáciách a zákona o dráhach.(ŽSR, 2020)

\section{ANALÝZA NEHODOVEJ UDALOSTI NA ŽELEZNIČNOM PRIECESTÍ}

Pre vykonanie analýzy nehodového deja a zist'ovania možných vplyvov na vznik a priebeh nehodovej udalosti sa v predmetnom príspevku autori venujú nehode kategórie A3 - zrážka vlaku s autobusom na železničnom priecestí. Nehodová udalost' sa stala v medzistaničnom úseku Hel’pa - Polomka na nezabezpečenom železničnom priecestí. K predmetnej nehode došlo tak, že autobus odbočil z hlavnej cesty doprava a bez zastavenia vošiel na železničné priecestie, ktoré sa nachádza cca $19 \mathrm{~m}$ od pravého okraja hlavnej cesty. Na železničné priecestie autobus vošiel práve vtedy, ked' sa ku železničnému priecestiu zl'ava z pohl'adu vodiča autobusu blížil motorový vlak zložený z motorového vozňa a vozňa. Autobus bol takto tlačený $26 \mathrm{~m}$ až do zastavenia vlaku. Z pohl'adu nehodových udalostí v rámci Slovenskej republiky ide o najtragickejšiu nehodu, pri ktorej zahynulo 12 osôb, 6 účastníkov nehody utrpelo t'ažké zranenia a 19 osôb bolo l’ahko zranených.

Pri analýze nehodového deja - zrážka vlaku s autobusom bolo nutné zistit' akým spôsobom sa pohyboval autobus pred nehodou, aké boli časovo - priestorové vzt'ahy s väzbou na prichádzajúci vlak, aký bol technický stav vozidla a jeho možný vplyv na vznik a priebeh dopravnej nehody. Na tieto otázky je možné odpovedat' matematicko-grafickou analýzou pohybu vozidla s využitím počítačovej simulácie a podrobnou diagnostikou brzdového systému, riadenia, prevodového systému a podvozkovej časti. (Kasanický - Kohút - Lukášik, 2001). Celková situácia miesta dopravnej nehody je znázornená na obrázku 4.

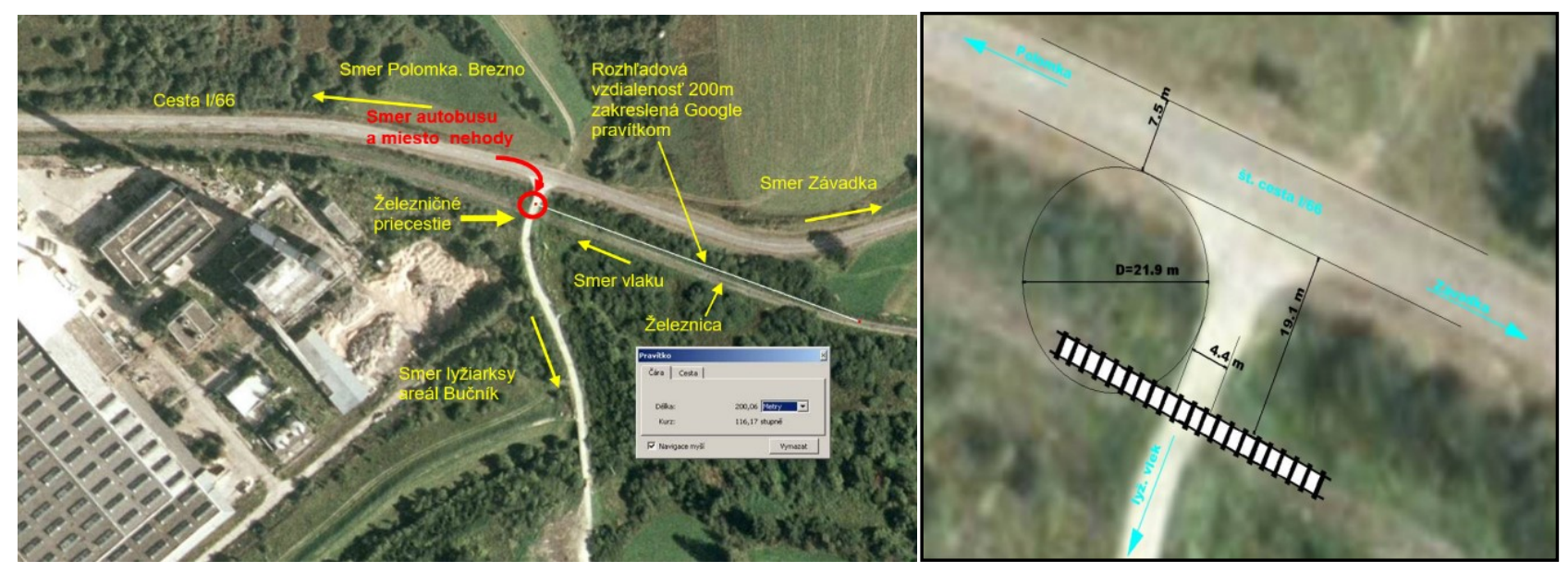

Obr. 5 Situácia mesta vzniku dopravnej nehody (Kohút, 2009)

Pri analýze vzájomného pohybu autobusu s vlakom pred nárazom je dôležité poznamenat', že pohyb uvedených dopravných prostriedkov pred nárazom vyplýva z analýzu rázu. Pri výpočte rázu sa zistilo, že vlak mal v momente nárazu rýchlost' $54 \mathrm{~km} \cdot \mathrm{h}^{-1}$ a autobus sa pohyboval rýchlost'ou medzi 8 a $10 \mathrm{~km} . \mathrm{h}^{-1}$. V nasledujúcich častiach je uvedená analýza celkovej situácie pred zrážkou.

Čas 11,0 sekúnd pred zrážkou - vlak sa nachádza cca 200 m od priecestia, autobus začína odbočovanie z hlavnej cesty. Vodič autobusu ešte nemá priamy dohl'ad na vlak, nakol'ko sa vlak nachádza v priestore zakrytého výhl'adu pre vodiča autobusu. Zo železničného priecestia je už vlak rozpoznatel'ný. Pôdorysný pohl'ad na polohu vlaku a autobusu 11 sekúnd pred nárazom. 


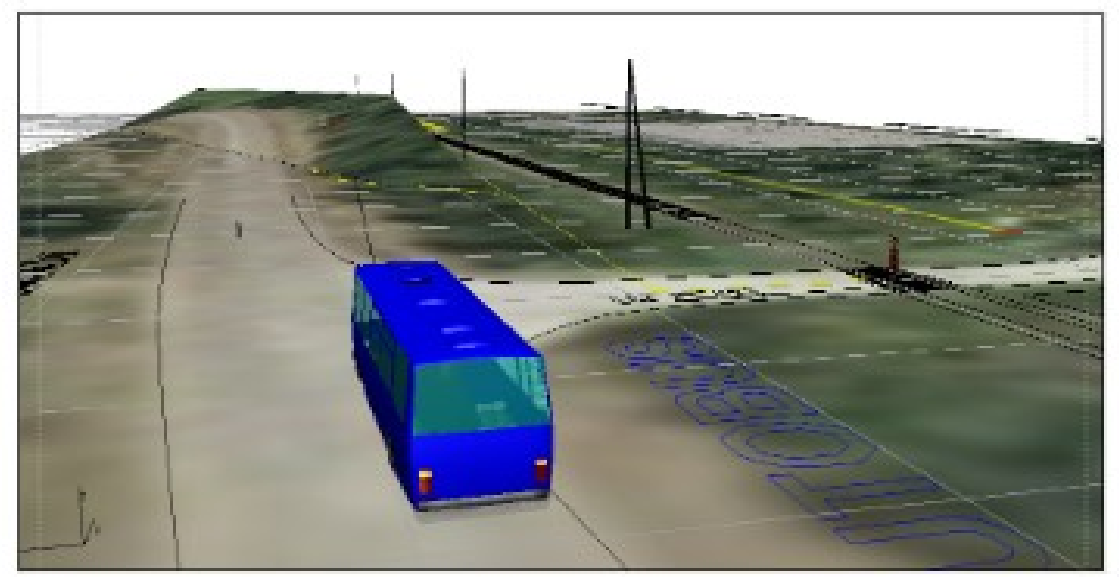

Obr. 6 Pohyb autobusu 11 sekúnd pred nárazom (Kohút, 2009)

Čas 7.2 sekundy pred nárazom - vlak sa nachádza $132 \mathrm{~m}$ od priecestia. Vlak je už rozpoznatel'ný z 10 metrovej vzdialenosti od priecestia, ale vodič autobusu ešte vlak nevidel, nakol'ko sa autobus nachádzal vo väčšej vzdialenosti ako 10 metrov.

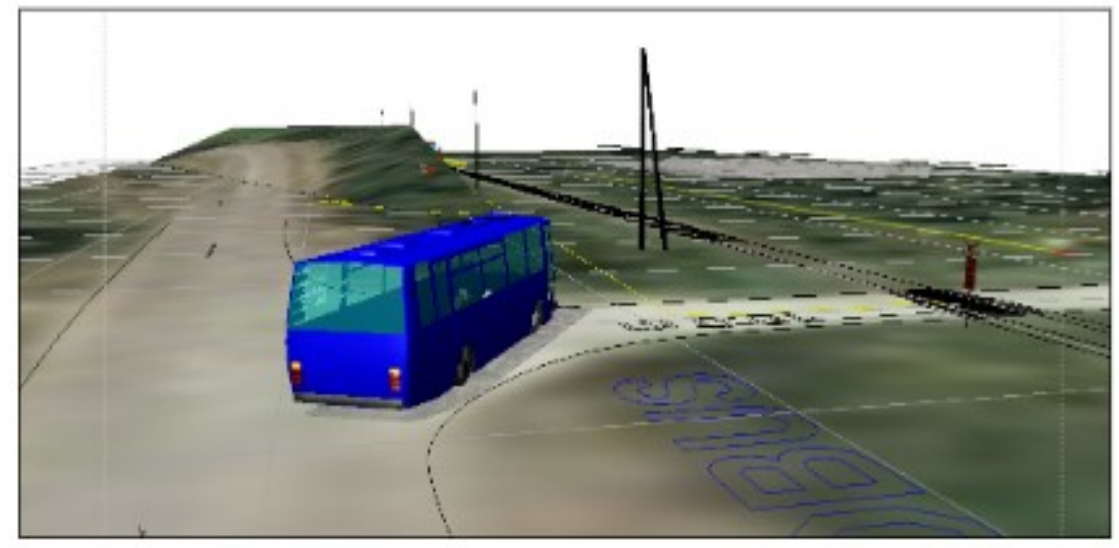

Obr. 7 Pohyb autobusu 7,2 sekúnd pred nárazom (Kohút, 2009)

Čas 5,8 sekundy pred nárazom - vlak sa nachádza vo vzdialenosti cca $105 \mathrm{~m}$ od priecestia a autobus cca $10 \mathrm{~m}$ od osy priecestia. $\mathrm{V}$ tomto momente majú na seba vzájomný rozhl'ad vodič autobusu, aj rušňovodič vlaku. Rušňovodič ešte nemôže predpokladat', že autobus nezastaví. Vodič autobusu mal možnost' začat' reagovat'. Na zastavenie z rýchlosti $10 \mathrm{~km} \cdot \mathrm{h}^{-1}$ potreboval dráhu 2,7 m. K bezpečnej vzdialenosti od železnice bolo ešte $6 \mathrm{~m}$.

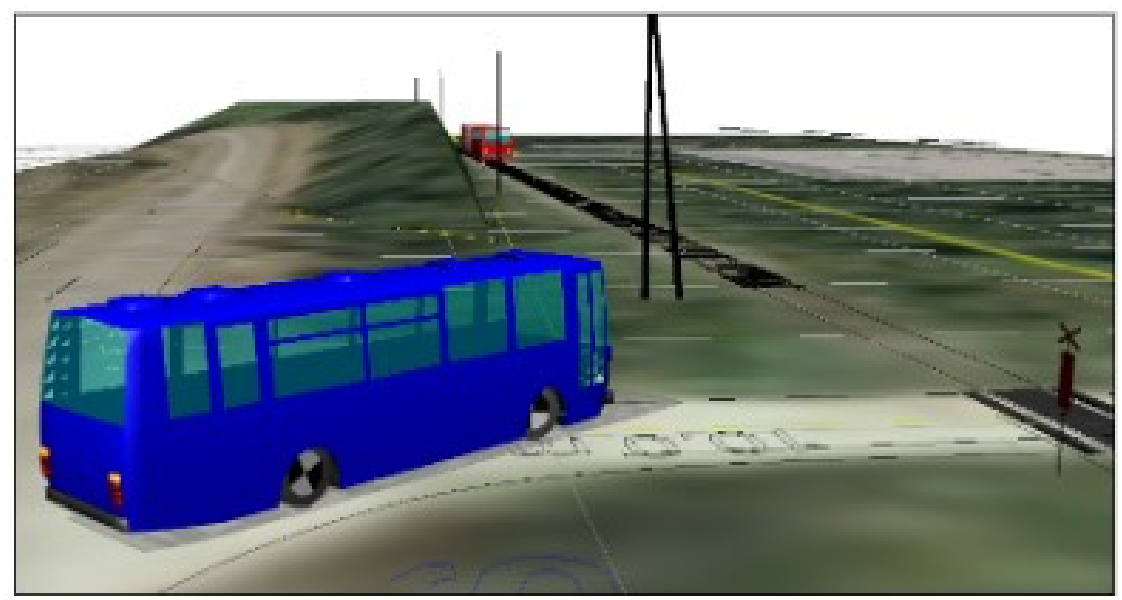

Obr. 8 Pohyb autobusu 5,8 sekúnd pred nárazom (Kohút, 2009) 
Čas 4,8 sekundy pred nárazom -vlak sa nachádza cca 85 m od miesta nárazu. Autobus sa nachádza 6,8 m od osy kol'ajiska. Autobus je práve vo vzdialenosti, kedy najneskôr mal vodič začat' reagovat', aby z rýchlosti $10 \mathrm{~km} . \mathrm{h}^{-1}$ dokázal s autobusom zastavit' v bezpečnej vzdialenosti pred kol'ajiskom, to znamená 4,0 m od osy kol'ajiska.

Výpočet: $S_{Z}=\frac{v^{2}}{2 \cdot a_{s}}+v \cdot t_{r}$

Stredné spomalenie vozidla: $\mathrm{a}_{\mathrm{s}}=5 \mathrm{~m} \cdot \mathrm{s}^{-2}$

Rýchlost' vozidla: $\mathrm{v}=2,8 \mathrm{~m} . \mathrm{s}^{-1}$

Čas reakcie vodiča: $t_{r}=0,7 \mathrm{~s}$

Dráha potrebná na zastavenie vozidla: $S_{z}=2,74 \mathrm{~m}$

Vzdialenost' od kol'ajiska pre najneskoršiu reakciu $4 \mathrm{~m}+2,74 \mathrm{~m}=6,74 \mathrm{~m}$.

Pri rýchlosti autobusu $10 \mathrm{~km} . \mathrm{h}^{-1}$ mal vodič 1 sekundu na rozpoznanie vlaku, aby po rozpoznaní dokázal reagovat' a zastavit' autobus v bezpečnej vzdialenosti od kol'ajiska.

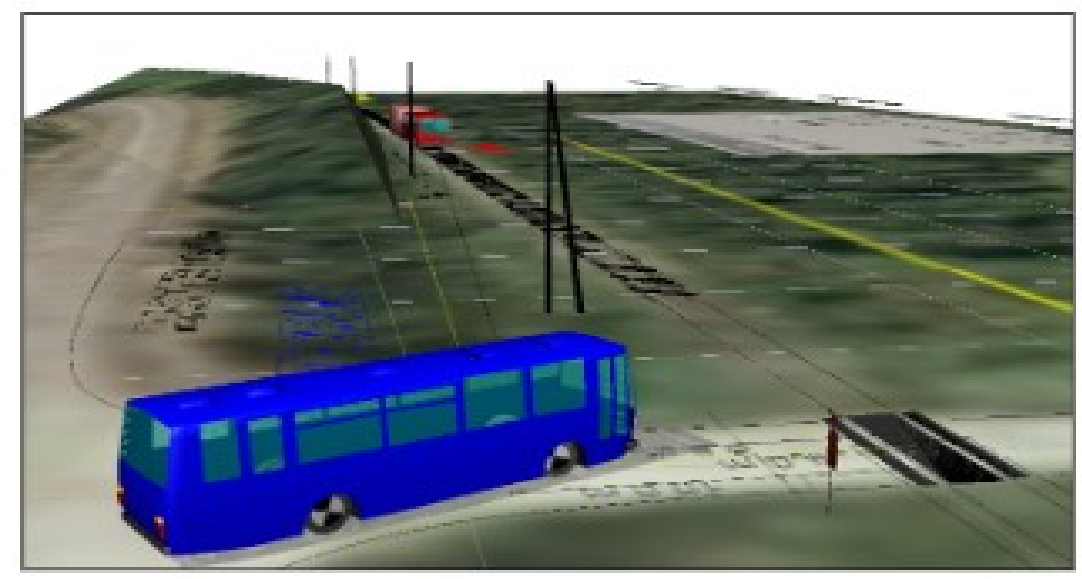

Obr. 9 Pohyb autobusu 4,8 sekundy pred nárazom (Kohút, 2009)

Čas 3,0 sekundy pred nárazom - v tomto momente rušňovodič použil rýchločinnú brzdu. Brzda začala účinkovat' až o 1,0 sekundu po nábehu tlaku vzduchu v brzdovej sústave.

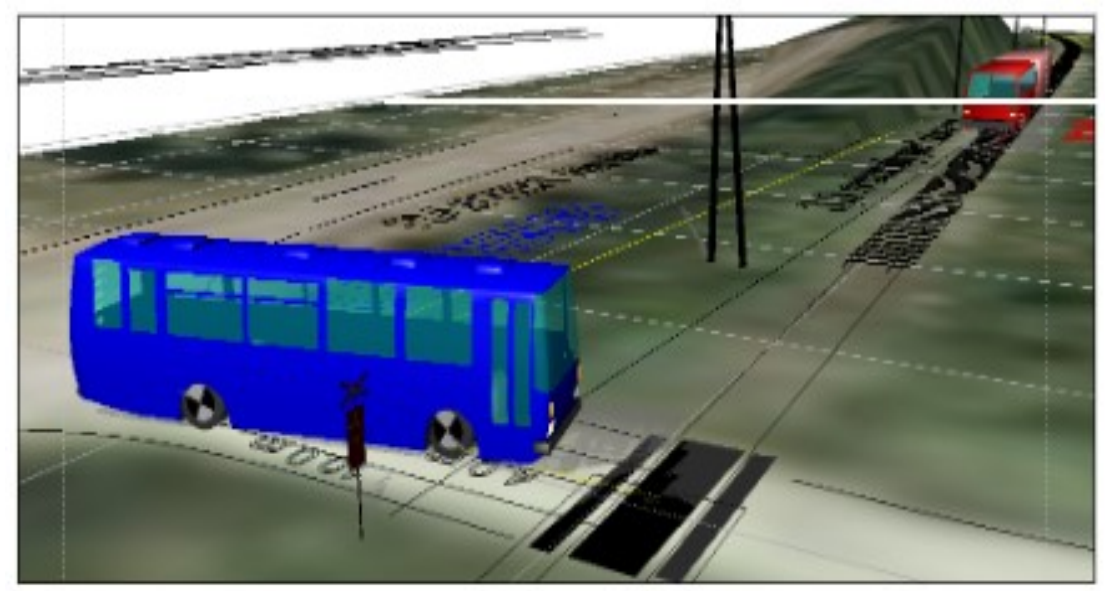

Obr. 10 Pohyb autobusu 3 sekundy pred nárazom (Kohút, 2009) 
Čas 2,0 sekundy pred nárazom - v tomto momente začína účinkovat' rýchločinná brzda. Vlak nemá žiadnu možnost' zastavit'. Napriek použitiu rýchločinnej brzdy vlak spomalí zo $70 \mathrm{~km} / \mathrm{h}$ na nárazovú rýchlost' $54 \mathrm{~km} / \mathrm{h}$.

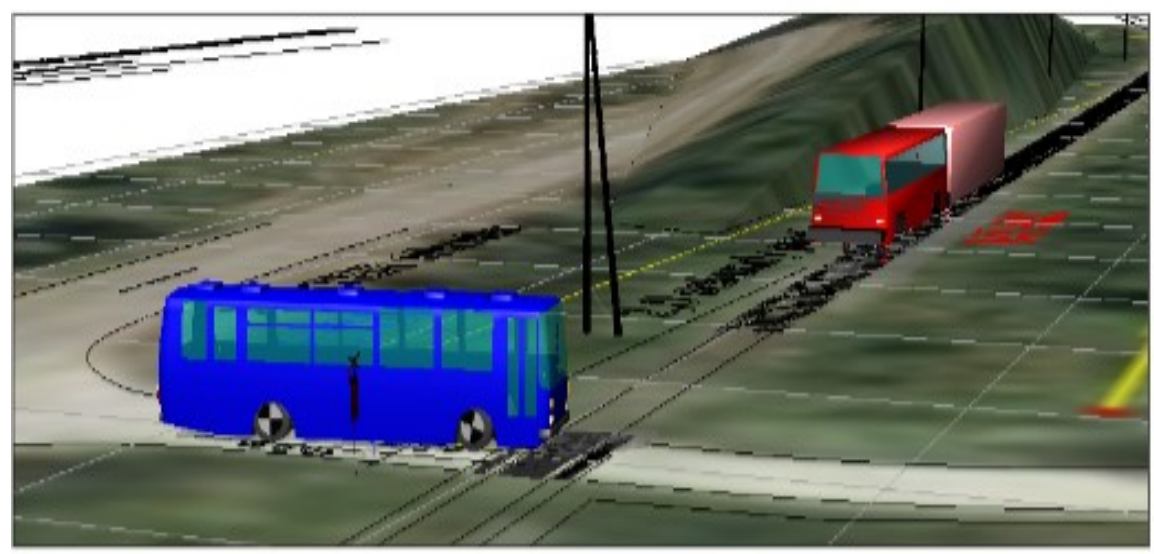

Obr. 11 Pohyb autobusu 2 sekundy pred nárazom (Kohút, 2009)

Podl'a uvedeného vyplýva, že vodič autobusu pri rýchlosti $10 \mathrm{~km} \cdot \mathrm{h}^{-1}$ mal možnost' spozorovat' prichádzajúci vlak minimálne 1,0 sekundu na 3,2 m dlhom úseku pred miestom, kde mal najneskôr začat' reagovat' a potom brzdit', aby dokázal zastavit' v bezpečnej vzdialenosti od železnice. Uvedený čas a úsek možno pokladat' za dostatočný, pričom nič nebránilo vodičovi autobusu jazdit' pomalšie, čím by sa potrebný čas na rozpoznanie prichádzajúceho vlaku predížil. Podl'a zisteného pohybu autobusu vodič autobusu vôbec nereagoval na prichádzajúci vlak.

Analýzou bolo zistené, že rušňovodič reagoval vtedy, ked’ mal možnost’ prvý krát rozpoznat', že autobus blížiaci sa ku kol’ajisku nedokáže zastavit' v bezpečnej vzdialenosti od kol'ajiska. Podl'a vykonanej analýzy rušňovodič reagoval včas, ihned', ako bolo možné rozpoznat' nebezpečenstvo zrážky s blížiacim sa autobusom.

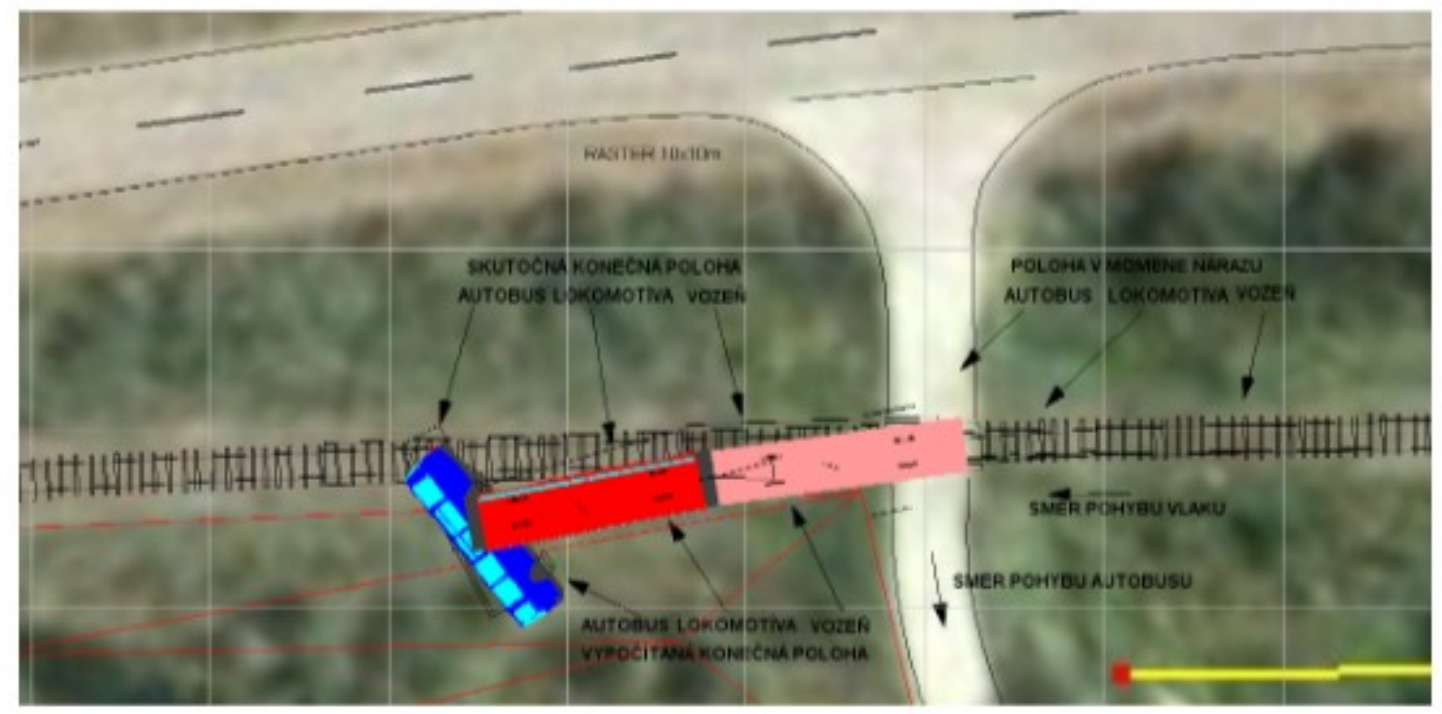

Obr. 12 Dimenzionálne znázornenie výpočtu rázu (Kohút, 2009)

Celková analýza bola vykonaná pre časový úsek 15 sekúnd pred nárazom. Na obrázku 11 je uvedené najjednoduchšie grafické znázornenie pohybu vlaku a autobusu pred zrážkou. 

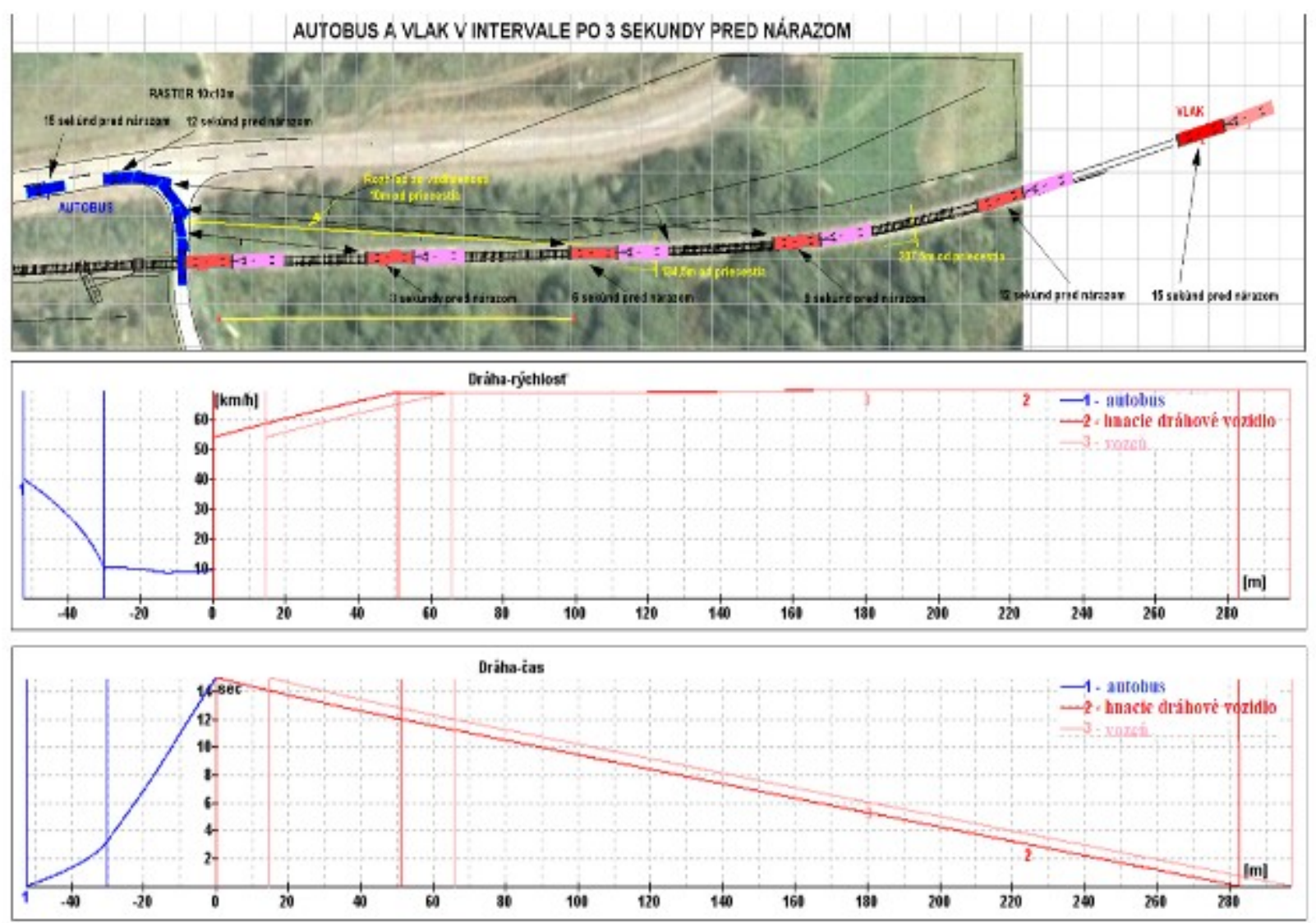

Obr. 13 Grafické znázornenie výsledkov výpočtu pohybu pred nárazom (Kohút, 2009)

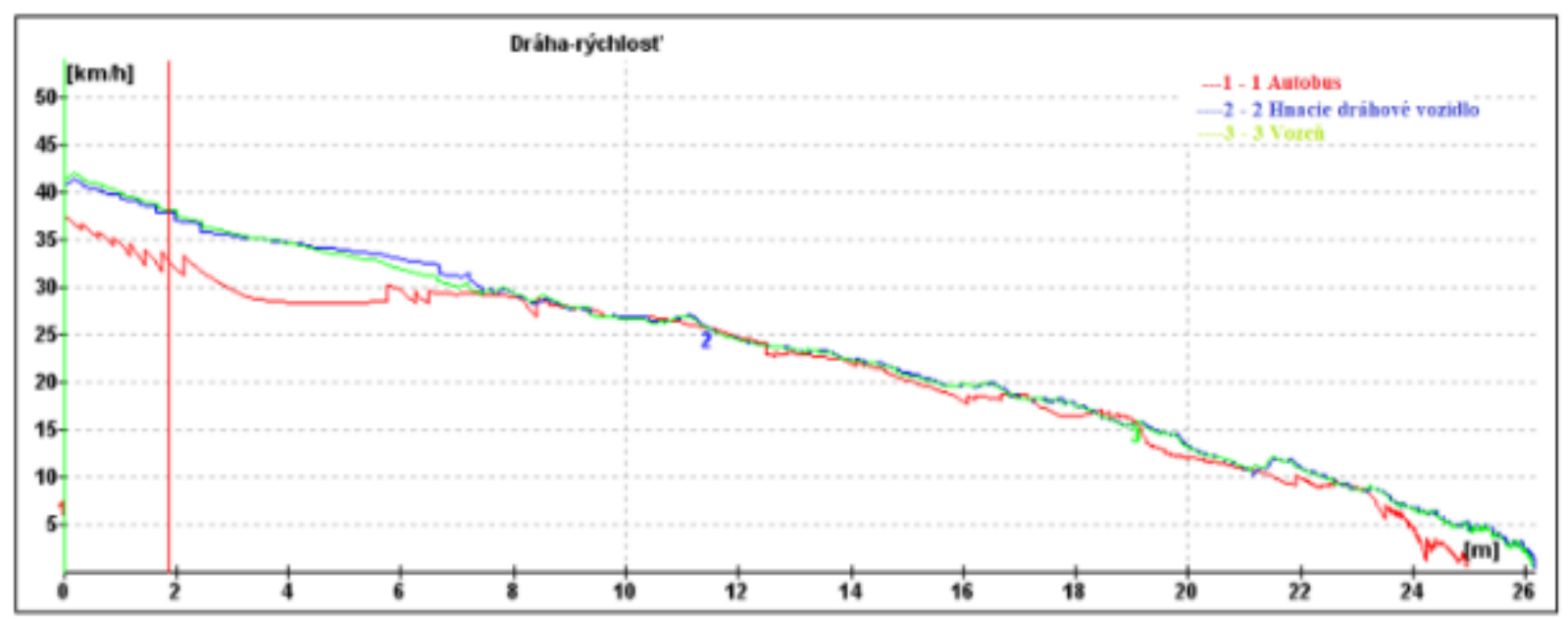

Obr. 14 Graf vypočítaného pohybu vozidla po náraze (Kohút, 2009)

Analýzou nehody neboli zistené žiadne okolnosti, ktoré by vodičovi bránili v dostatočnej vzdialenosti od železničného priecestia uvidiet' prichádzajúci vlak a správne reagovat'. Vodič motorového vlaku reagoval včas vtedy, ked' mal možnost' prvý krát rozpoznat', že autobus bližiaci sa k železničnému priecestiu nezastaví. Po začatí reakcie vodič motorového vlaku využil maximálnym spôsobom všetky dostupné technické možnosti na zastavenie vlaku, na odvrátenie a na zmiernenie následkov nárazu vlaku do autobusu. Možnosti zabránenia nehode zo strany vodiča autobusu, v tomto prípade iba vodič autobusu mal všetky možnosti zabránit' dopravnej nehode. Pri celkovej analýze nehody a technického stavu autobusu neboli zistené žiadne okolnosti, ktoré by vodičovi bránili pred vjazdom na priecestie včas rozpoznat' prichádzajúci vlak, správne na situáciu reagovat’ a zastavit’ autobus v bezpečnej vzdialenosti od vlakového priecestia. 


\section{PREVENTÍVNE OPATRENIA NA ŽELEZNIČNÝCH PRECESTIACH}

Najdôležitejšou oblast'ou je prevencia a snaha o opakované upozorňovanie užívatel'ov pozemných komunikácii na povinnost' dodržiavania pravidiel cestnej premávky pri križovaní pozemnej komunikácie so železničnou trat'ou.

ŽSR pravidelne vykonávajú v spolupráci s PZ SR monitorovanie dodržiavania pravidiel prechádzania cez železničné priecestia zo strany účastníkov cestnej premávky a rešpektovanie dodržiavania zastavenia pred priecestím podl'a ustanovení zákona NR SR č.8/2009 Z. z. o cestnej premávke v znení neskorších predpisov prostredníctvom kontrol priamo v teréne, pričom zist’ujú značné porušenia zo strany vodičov cestných vozidiel, ale i chodcov a bicyklistov. Taktiež vybrané priecestia monitorujú kamerovými systémami, ktorých záznam je v prípade potreby poskytnutý orgánom činným v trestnom konaní.

V oblasti prevencie sa v rámci Medzinárodného dňa bezpečnosti na železničných priecestiach vykonávajú rôzne simulované zrážky či iné prezentácie pre médiá, vzdelávanie žiakov autoškôl, vzdelávanie detí v materských a v základných školách, ako aj informovanie cestujúcich prostredníctvom rôznych letákov, videí na železničných staniciach, atd'.

V d'alšom období bude jedným z možných riešení nad'alej znižovat' celkový počet železničných priecestí, ktoré sú neustále možným kolíznym bodom stretu železničného a cestného vozidla, ako aj budovat' mimoúrovňové kríženia formou nadjazdov alebo podjazdov.

Článok bol vytvorený s podporou vedeckovýskumného projektu VEGA 1/0159/19 Hodnotenie úrovne odolnosti klúčových prvkov pozemnej dopravnej infraštruktúry.

\section{ZÁVER}

Železničné priecestie predstavuje miesto križovania pozemnej komunikácie so železničnou siet’ou. 0 každom železničním priecestí sú evidované údaje, a to správcovské číslo, identifikačné číslo, počet kol'ají, druh zabezpečnia, rok stavby a JIČ ŽSR (jednoznančý identifikátor správcu priecestia).

Pri rôznych nehodových udalostiach na železničných priecestiach predstavujú najväčšie ohrozenie účastníci cestnej premávky. Z uvedeného dôvodu vykonávajú ŽSR opatrenia, ktoré vedú k zvýšeniu bezpečnosti na železničných priecestiach prostredníctvom rôznych aktivít.

Z pohl'adu analýzy priebehu nehodového deja na železničnom priecestí, ktorá je v predmetnom príspevku analyzovaná je zrejmé, že jedinou príčinou nehody z technického hl'adiska bolo nesprávne konanie vodiča autobusu. Tento vodič autobusu sa pred priecestím nepresvedčil, či môže bezpečne prejst' cez železničné priecestie a vošiel na železničné priecestie v čase, ked' už mohol vidiet' prichádzajúci vlak. V tomto prípade došlo k zlyhaniu l'udského faktora.

\section{Literatúra}

Kohút, P. 2009. Znalecký posudok. Ústav súdneho inžinierstva ŽU v Žiline.

Kasanický, G., Kohút, P., Lukášik, M. 2001. Teória pohybu a rázu pri analýze a simulácii nehodového deja. Žilina: Žilinská univerzita, 2001. 350 s. ISBN 80-7100-597-5

Svensson, Å. 1992. Vidareutveckling och Validering av Den Svenska Konflikttekniken (Eng. Further Development and Validation of the Swedish Traffic Conflicts Technique). Dept. of Traffic Planning and Engineering, Lund University, Lund, Sweden

Šimák, L., Horáček, J., Novák, L., Németh, L., Míka, V. 2005. Terminologický slovník krízového riadenia, Žilinská univerzita v Žiline - Fakulta špeciálneho inžinierstva. ISBN 80-88829-75-5 
European Union. 2020. Report on Railway Safety and Interoperability in the EU. Dostupné na: https://www.era.europa.eu/sites/default/files/library/docs/safety interoperability progress reports/r eport on railway safety and interoperability in the eu 2020 en.pdf

ŽSR. 2020. Železničné priecestia všeobecne. Dostupné na: https://www.zsr.sk/sluzby-verejnosti/vsetkozeleznicnych-priecestiach/zeleznicne-priecestia-vseobecne/

ŽSR. 2020. Štatistika nehodovosti na železničných priecestiach. Dostupné na: https://www.zsr.sk/slovensky/media-room/vyjadrenia-pre-media-2017/januar/statistika-nehod-nazeleznicnych-priecestiach.html 